\title{
SUSTAINABILITY BUSINESS MODELS IN MILK PROCESSING. CONSIDERATIONS BASED ON THE POLISH EXPERIENCE
}

\author{
Renata Grochowska ${ }^{1}$, Iwona Szczepaniak ${ }^{1 凶}$ \\ ${ }^{1}$ Institute of Agricultural and Food Economics - National Research Institute, Poland
}

\begin{abstract}
The objective of this paper was to present the activities undertaken in selected dairy plants in Poland as part of sustainability business models to address and reduce food losses in economic, environmental and social dimensions. Therefore, a case study method was used in three dairy plants of different production volume and structure, as well as in ten agricultural holdings supplying these plants with raw milk. The study indicates that in the last two decades of modernization, Polish dairy plants have aligned their operations with the sustainability business model focused on maximizing material and energy efficiency. This is evidenced by such activities as the optimal use of resources at different production stages, lower water and energy consumption and reduced emissions of pollutants. Opportunities for further development of dairy companies lie in activities consistent with other sustainability business models which are not only technological, but also social and organizational in nature. Their implementation may provide new sources of competitive advantages for companies in the era of growing competition. This is true not only for the dairy industry but also for other agri-food sub-sectors.
\end{abstract}

Keywords: sustainable development, Polish dairy industry, food losses

\section{INTRODUCTION}

The neoclassical model of enterprise operations - which seeks maximization of profits at any cost - is less and less consistent with the present conditions, i.e. ongoing climate change, depletion of natural resources, growing consumerism and food waste. The increase in production costs (raw materials, energy, labor etc.), combined with the growing pressure from competitors and consumers, make enterprises seek new solutions not only to survive in the market but also to become sector leaders and major business partners.

More and more enterprises see such opportunity in implementing sustainability business models which make it easier to build a competitive edge through measures that positively affect and/or reduce the adverse environmental and social impacts. Scientific literature on the subject presents various classifications of sustainability business models, and attempts to clarify the mechanisms of how sustainability is achieved. In economic practice, enterprises facing various types of resource limitations create their own strategies.

Therefore, the objective of this paper was to present the activities undertaken in selected dairy plants in Poland within the framework of sustainability business models designed to address and reduce food losses in economic, environmental and social dimensions. Focus was placed on the dairy sector due to the importance of milk production for the sustainability of food management and the significant environmental impacts of this sector (high consumption of water and energy; large amounts of losses and pollution generated in production and distribution processes). The relatively low profitability of the dairy industry, forcing enterprises to seek

\footnotetext{
Iwona Szczepaniak, PhD, Institute of Agricultural and Food Economics - National Research Institute, Świętokrzyska 20 St., 00-002 Warsaw, Poland, e-mail: Iwona.Szczepaniak@ierigz.waw.pl, https://orcid.org/0000-0002-151 1-4428
} 
new ways of doing business and new sources of competitive advantage, provided an additional incentive in this regard.

\section{CONCEPTUAL FRAMEWORK}

The literature provides various perspectives on how to approach the business model. One of the first definitions was presented by Timmers (1998) who treated the business model as a set of elements such as: the architecture of the product, service and information flow; the characteristics of potential benefits achieved by various business actors; and the nature of revenue sources. Together with other early definitions of the business model, the above placed greater emphasis on how to achieve sales revenue than on how to focus corporate activities on profits (Wierzbiński, 2015). In following years, the essence of the business model has been increasingly linked with the need to generate profits, thereby extending the definition to cover new elements. Magretta (2002) was one of the first researchers who suggested that the creation of customer value and enterprise value should be combined together. In turn, Afuah and Tucci (2003) defined the business model as a way to enhance and use the resources so as to provide customers with products and services of a value higher than what is offered by competitors. A resource-based approach to the business model was also followed by Obłój (2010) who claimed that each business model consists of resources (including intangible ones) and strategic skills needed to create enterprise value. The concept of business model was also defined in terms of processes. According to Teece (2010), the business model - considered as a way to generate customer value which translates into business profits - should begin by introducing a product or technological innovation. Innovations alter the entire structure of the business model which means that its creation is a continuous process. On the other hand, Osterwalder and Pigneur (2010) proposed a systemic approach to the business model, assuming it to be composed of several logically interrelated elements, i.e. social, economic and environmental aspects. Zott and Amit (2010) perceived it in a slightly different way. According to them, the business model is a specific set of activities and relationships between them which contributes to creating value for customers, the enterprise and other stakeholders of the model. In this approach, the business model goes beyond the boundaries of the enterprise.
The above definitions indicate various operational aspects of a business model. The understanding of this concept has clearly evolved due to existing resource limitations affecting enterprises and the need to adapt to new challenges they face in a competitive environment. According to the authors, the systemic approach to the business model seems to be the most consistent with economic realities as it takes into account the multifaceted relationships, interactions and dependencies between the model's components. In the era of the development of global value chains, anyone who acts single-handedly is doomed to fail. Vertical integration structures become less and less important while complex networks of interrelations grow in significance.

In a specific case when the business model is underpinned by sustainable development principles, it becomes a sustainability business model, and its overarching mission is to implement strategic objectives of various stakeholder groups (Boons et al., 2013). These objectives mean gaining a competitive advantage in the market, increasing corporate value and ensuring business continuity. This process takes place through a constructive confrontation of individual elements, functions and resources of the enterprise (with economic, environmental and social criteria being taken into account) (Jabłoński, 2013). The innovation of sustainability models consists in that the enterprise and the networks where it operates actually create, deliver or capture economic value which generates positive and/or reduces negative environmental and/or social effects (Boons and LüdekeFreund, 2013). Innovation makes enterprises change the way they do business so as to maximize economic benefits they earn while optimizing social and environmental benefits (Bocken et al., 2013).

Schaltegger et al. (2012) identified three basic groups of business models used by enterprises i.e. the defensive, accommodative and proactive model. The first one consists in gradual adjustments made to protect the existing model through a reduction of risks and costs. In the second, modifications are made to internal enterprise processes; certain environmental protection objectives are included; and the society gets incorporated into the framework of the modified strategy. The third group essentially reformulates the logic of business activity to make it consistent with sustainable development principles.

The literature addressing sustainability business models is ample but dispersed. There are many concepts 
and approaches in this regard. This limits the practitioners' ability to implement the models into commercial practice despite the obvious benefits of doing so. In order to address these needs, Bocken et al. (2014) developed a classification of sustainability business models by grouping various mechanisms and solutions which may contribute to building them. They mentioned mainly the ones consistent with sustainable development principles, i.e. those involving a lower consumption of energy and raw materials and reduced emissions and losses per production unit. It was assumed that these should be long-term solutions suitable not only for a single enterprise but for entire sectors, so as to meet the current and future challenges (limited access to raw materials, water and energy). However, note that while the direct impact of increased efficiency and production quality on profits is well understood (traditional business models), it is not obvious how environmental and social benefits may translate into business profits and competitive advantages (sustainability models).

Bocken et al. (2014) grouped sustainability business models into three basic categories, i.e. those geared towards technological, social or organizational innovations (Fig. 1). The first one includes subtypes focused on the innovative technical component, such as an industrial process or the development of a new product. The second (social) category concerns subtypes with a dominant social component, e.g. innovations in offers targeted at consumers or changes in the field of consumer service. In the third category, focus is on the organizational component which enables innovative changes in the company's organization (e.g. fiduciary liability).

This paper focuses on the technological component which includes three subtypes of sustainability business models:
- Maximizing material and energy efficiency: a subtype which assumes cost reduction through an optimum use of resources at different production stages to reduce losses, resource wastage, greenhouse gas emissions and environmental pollution. This leads to increased profits and stronger price competitiveness, has a positive social impact and minimizes negative environmental impacts. Activities are primarily based on product and process innovations. However, that model may also apply to broader changes, such as reconfiguring the value network through efficiency improvements and a reduction in pollutant emissions (e.g. based on sustainable transport).

- Creating value from waste: a model based on eliminating losses by using waste as raw materials for further production and processes. It does not seek to reduce waste at any expense, but treats it in a new way, as something useful which can be reused. A similar pattern can be found in nature: waste is raw material for the subsequent links of the food chain. Economic and environmental costs are reduced by reusing waste and treating it as a valuable resource in its own right. The reduced environmental burden clearly has positive social and environmental impacts due to lower pollutant emissions, better use of raw materials, water and energy, and lower amounts of waste. New networks of dependencies are created, e.g. through the inclusion of recycling companies into the value chain.

- Substitution with renewables and natural processes: a model which seeks to reduce the negative environmental impact of the industry (faced with the existing resource limitations) by using renewables and processes taking place in nature, so as to create more environmentally-friendly industrial processes.

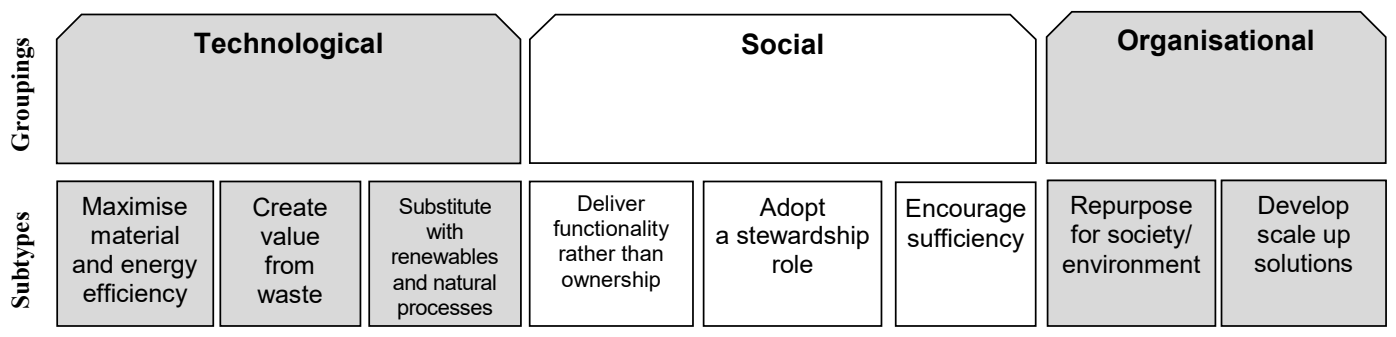

Fig. 1. Subtypes of sustainable business models Source: Bocken et al., 2014. 
Business profits are generated along with implementing new, innovative products and processes. A positive value for the environment is the lower use of non-renewable resources, reduced pollutant emissions and reduced amounts of synthetic waste in landfills. The partnership network may be extended with companies related to renewable sources or waste recycling.

\section{MATERIAL AND METHODS}

A case study was carried out in order to examine the losses of food produced in the supply chain of milk and milk products at the initial two stages of the supply chain, i.e. production and processing. It covered ten farms producing raw milk and three plants which receive milk from these farms and process raw milk for dairy products manufacturing. They were located in the Mazowieckie, Podlaskie and Warmińsko-Mazurskie voivodeships. The dairy plants significantly differed in production volume and structure (Table 1). Four groups of farms were selected for the study: two farms supplying 10-40 thousand $\mathrm{kg}$ of milk per year; four farms supplying 40-120 thousand $\mathrm{kg}$ of milk per year (the most common production volume in dairy farms); two farms providing 120-400 thousand $\mathrm{kg}$ of milk per year; and two farms providing more than 400 thousand $\mathrm{kg}$ of milk per year. 2011-2013 data from agricultural holdings and plants was collected in June-November $2014^{1}$.

Production plants selected for this study are members of a capital group which leads the Polish dairy sector in

${ }^{1}$ The specific research methodology was presented in Seremak-Bulge et al., 2015.

Table 1. Milk buying-in and processing, and production of milk products in dairy plants surveyed in 2011-2013 (in thousand tons)

\begin{tabular}{|c|c|c|c|c|c|c|c|c|c|}
\hline \multirow{2}{*}{$\frac{\text { Specification }}{\text { Plant }}$} & \multicolumn{3}{|c|}{2011} & \multicolumn{3}{|c|}{2012} & \multicolumn{3}{|c|}{2013} \\
\hline & 1 & 2 & 3 & 1 & 2 & 3 & 1 & 2 & 3 \\
\hline Milk buying-in & 438.0 & 78.0 & 135.0 & 467.0 & 87.0 & 149.0 & 494.0 & 80.0 & 153.0 \\
\hline Milk processing & 695.0 & 97.0 & 58.0 & 735.0 & 111.0 & 116.0 & 775.0 & 117.0 & 153.0 \\
\hline Production of milk products & 408.0 & 11.0 & 5.1 & 445.0 & 11.0 & 10.6 & 496.0 & 11.0 & 15.8 \\
\hline including: liquid pasteurized milk & 159.0 & & & 173.0 & & & 192.0 & & \\
\hline UHT milk & 179.0 & & & 196.0 & & & 210.0 & & \\
\hline fermented products & 12.0 & & & 13.0 & & & 19.0 & & \\
\hline sour cream and cream & 4.0 & & & 9.0 & & & 13.0 & & \\
\hline ripened cheese & 25.0 & & 5.0 & 25.0 & & 10.0 & 28.0 & & 14.0 \\
\hline cheese and curd & 5.0 & 11.0 & & 3.0 & 11.0 & 0.1 & 4.0 & 11.0 & 1.0 \\
\hline butter and milk fats & 24.0 & & 0.1 & 26.0 & & 0.5 & 30.0 & & 0.8 \\
\hline Production of other products & 401.3 & 37.0 & 60.0 & 432.0 & 48.5 & 115.0 & 560.3 & 38.5 & 130.0 \\
\hline including: WMP & 0.2 & 1.0 & & 1.0 & 1.5 & & 0.3 & 1.5 & \\
\hline SMP & 2.0 & 3.0 & & 2.0 & 4.0 & & 2.0 & 5.0 & \\
\hline whey & 367.0 & 33.0 & 60.0 & 396.0 & 43.0 & 115.0 & 525.0 & 32.0 & 130.0 \\
\hline including: dried & 20.0 & & & 18.0 & & & 27.0 & & \\
\hline condensed milk & 0.1 & & & 2.0 & & & 2.0 & & \\
\hline processed cheese & 2.0 & & & 3.0 & & & 4.0 & & \\
\hline
\end{tabular}

Source: own elaboration based on Seremak-Bulge et al., 2015. 
terms of milk processing volumes (ca. 1.1 million tons in 2014), sales value of dairy products (PLN 3.88 billion) and employment (nearly 2,500 persons). In 2002-2014, the group invested PLN 892 million which represented $9.4 \%$ of total investment inputs of the Polish dairy industry. The investments became a basis for structural transformation and contributed to: upgrading technological processes; extending the scope of operations with the development of in-depth whey processing; upgrading the drying technology; and employment restructuring. These positive changes are also noticeable in the increased concentration of production, improvements in asset efficiency and productivity, gradual improvements to milk processing efficiency, and minimization of losses.

It is vital to stress that a distinction should be made between losses and unavoidable natural wastage occurring in technological processes (taken into account in production standards). Also, there may be avoidable wastage, caused for instance by organizational mistakes, human errors or a failure to adjust the production profile to technological lines. As a consequence, finished products are of a lower commercial quality, cannot be sold as full-quality products, and therefore constitute losses.

Losses occurring in agricultural holdings and milk processing plants were estimated using the questionnaire method. The following parameters were taken into account:

- losses incurred by farms producing milk, defined as raw milk which does not meet quality standards, is not accepted for further processing and is not used for production purposes, resulting in lower payments,

- losses incurred by dairy plants, defined as losses of products which, for commercial reasons, could not be sold as full-quality products. They were counted at the pre-treatment, processing and batching, packaging, storage and distribution stages.

Empirical data about losses was subjected to descriptive statistics that summarize these findings.

\section{RESULTS AND DISCUSSION}

This study suggests that despite differences in scale and production specialization, dairy plants relied on similar strategies to reduce losses. However, they mainly addressed the economic dimension with less emphasis on environmental and social dimensions. It may be concluded that the Polish dairy industry currently relies on the "Maximizing material and energy efficiency" business model. This model emerged together with modernization and investment processes aligning the Polish dairy industry with European Union's hygiene and veterinary standards and improving its competitiveness.

The economic transformation and integration with the EU in 2004 (and the related reforms) accelerated the development of the dairy industry which has evolved into one of the most advanced industries in Europe. Thus, it was able to offer the consumer an attractive range of quality dairy products at acceptable prices and to compete effectively in international markets. The adaptation to the market economy was supported by the price policy of dairy plants who rewarded high quality of milk and concentration of supplies. The key driver of investment and modernization processes in the dairy sector was the removal of barriers to intra-EU trade and free access to markets of other Member States. This resulted in a price increase and in improved profitability of milk production and processing in Poland.

The results of this study confirmed that dairy plants attached great importance to the quality of milk as early as at the stage of the resource base. The average share of total losses incurred by farms supplying milk to dairy plants was $0.4 \%$ of milk produced, varying in the range of 0.0 to $0.7 \%$ (Fig. 2). The main reason why a certain amount of milk failed to comply with quality standards is the presence of antibiotics in the milk of high-performance Afuah cows treated for inflammation of the udder (mastitis).

The emphasis placed on high-quality raw materials was also reflected in the efficient organization of milk collection. The following aspects prevailed: direct milk collection from farms; using services of specialized transport companies; relatively short average delivery distances; and (in the largest of the plants surveyed) a high concentration level of suppliers and milk supplies. Note that maintaining the cold chain during milk storage, collection and transport to dairy plants made it possible to preserve the high quality of raw milk, even though the collection frequency was reduced to every 2-3 days. As a consequence, transport costs of dairy raw material decreased, and so did the consumption of fossil fuels. In 2011, the total share of raw milk refused by dairy plants due to excessive temperature or presence of antibiotics in the total milk collection varied in the range of $0.06 \%$ to $0.09 \%$, and dropped to $0.03-0.04 \%$ in 2013 (Fig. 3). 

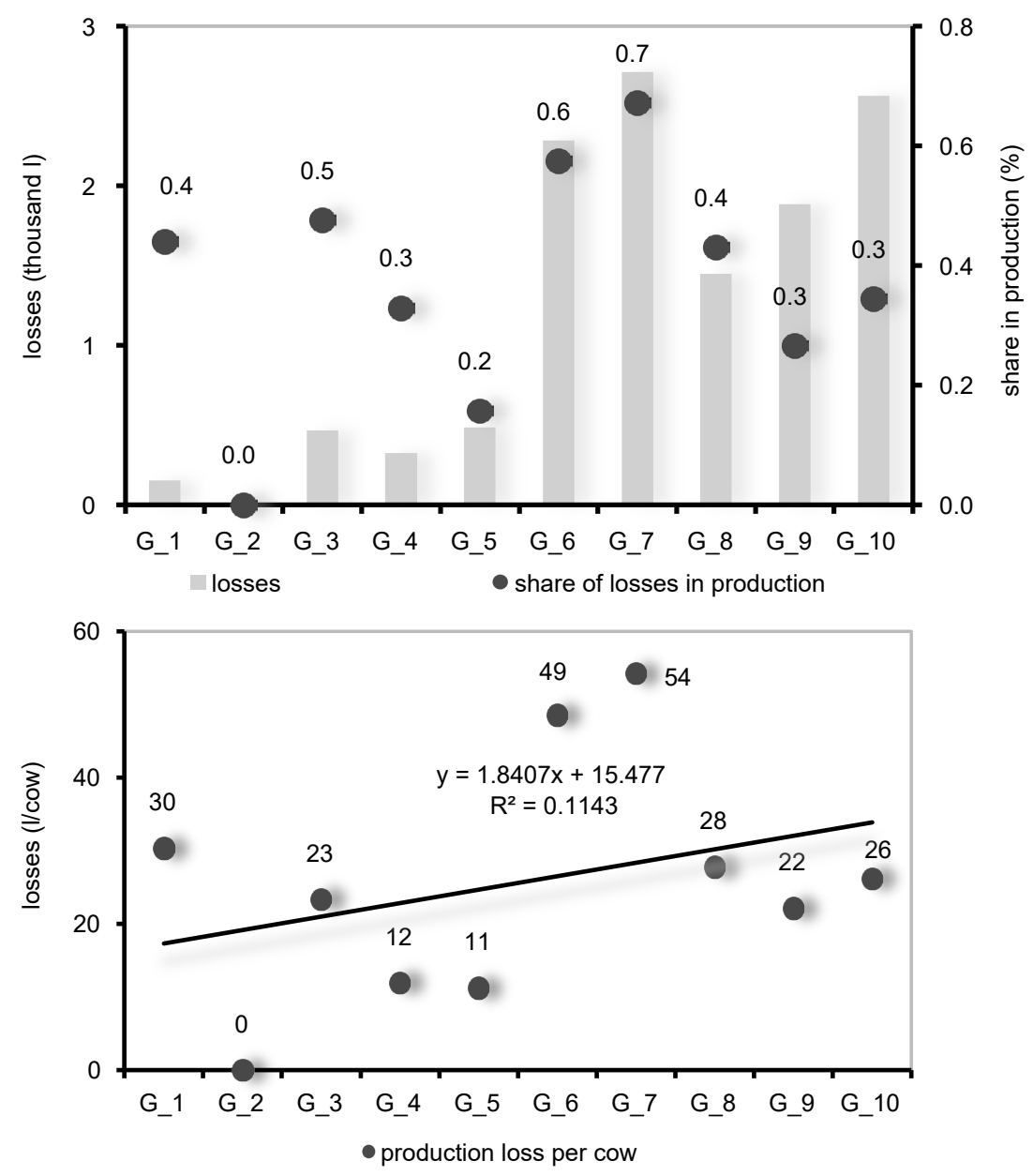

Fig. 2. Losses in total milk production and per cow. G1...G10: numbers of farms analyzed

Source: own elaboration based on Seremak-Bulge et al., 2015.

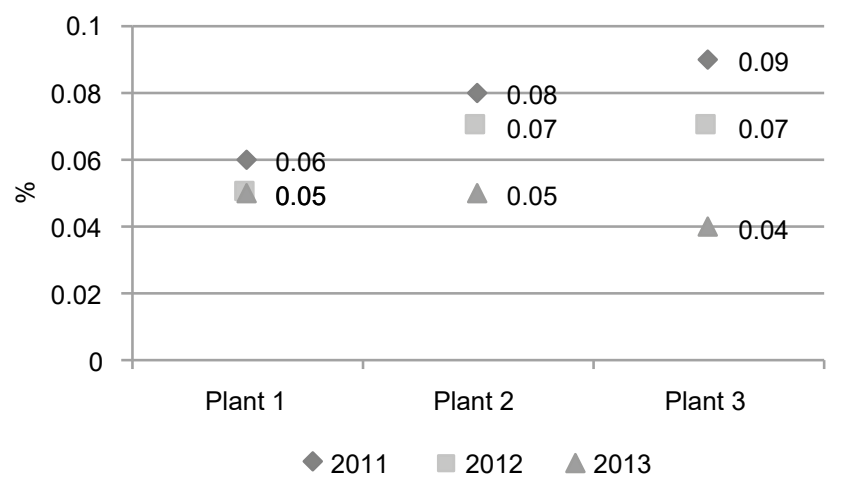

Fig. 3. Share of milk discarded due to excessive temperature and antibiotic content in total milk output in 2011-2013 (\%). Source: own elaboration based on Seremak-Bulge et al., 2015.
Also, milk losses at the processing stage were of marginal importance to the activity and income of dairy plants surveyed. The vast majority of losses occurring during production of dairy products were transferred for further processing or sold to employees at promotional prices. This is how 98-99\% of losses were handled. The remaining $1-2 \%$ was used as feed or sent to rendering plants. With such a small share, losses had only a minimal impact on income of dairy plants surveyed. The breakdown of losses incurred at various stages of the production process, i.e. pre-treatment, processing, batching, packaging, storage and distribution, is presented in Table 2. These findings are close to those reported in other research on diaries in developed countries (Dairy Technology, 2014). 
Grochowska, R., Szczepaniak, I. (2019). Sustainability business models in milk processing. Considerations based on the Polish experience. J. Agribus. Rural Dev., 2(52), 111-122. http://dx.doi.org/10.17306/J.JARD.2019.01104

Table 2. Share of losses in the production of particular product groups by phase of the production process (\%)

\begin{tabular}{|c|c|c|c|c|}
\hline Product & Pre-processing & $\begin{array}{l}\text { Processing } \\
\text { and batching }\end{array}$ & $\begin{array}{l}\text { Packaging } \\
\text { and storage }\end{array}$ & Distribution \\
\hline \multicolumn{5}{|l|}{ Plant 1} \\
\hline Liquid pasteurized milk & 0.01 & 0.001 & \multirow{4}{*}{0.001} & \multirow{7}{*}{0.001} \\
\hline UHT milk & 0.01 & 0.001 & & \\
\hline Fermented products & 0.01 & 0.001 & & \\
\hline Sour cream and cream & 0.01 & 0.001 & & \\
\hline Ripened cheese & 0.01 & 0.001 & $\begin{array}{l}3.0^{\mathrm{a}} \\
8.0^{\mathrm{b}}\end{array}$ & \\
\hline Cheese and curd & 0.01 & 0.001 & \multirow{2}{*}{0.001} & \\
\hline Butter and milk fats & 0.01 & 0.001 & & \\
\hline \multicolumn{5}{|l|}{ Plant 2} \\
\hline Cheese and curd & 0.01 & 0.001 & 0.001 & 0.002 \\
\hline \multicolumn{5}{|l|}{ Plant 3} \\
\hline Ripened cheese & 0.01 & 0.001 & $\begin{array}{l}3.0^{\mathrm{a}} \\
8.0^{\mathrm{b}}\end{array}$ & 0.001 \\
\hline Cheese and curd & 0.01 & 0.001 & 0.001 & 0.002 \\
\hline Butter and milk fats & 0.01 & 0.001 & 0.001 & 0.001 \\
\hline
\end{tabular}

${ }^{a}$ Drying, i.e. cheese weight loss due to water evaporation.

${ }^{\mathrm{b}}$ Cheese scraps, i.e. losses generated during batching and packaging.

Source: own elaboration based on Seremak-Bulge et al., 2015.

The dairy plants attached great importance to reducing the share of products not meeting commercial requirements in the total production volume through such activities as: using mandatory and non-mandatory food safety and quality management systems; using advanced technological lines maintained in good technical condition; making efforts to properly organize work related to maintaining the current efficiency of production lines and cleanness of equipment and production rooms; systematic quality inspection of semi-finished products and final products at different stages of the production process. Also, loss ratios were monitored on a regular basis and, where necessary, organizational and managerial measures were taken to reduce them.

At the finished product distribution stage, the amount of losses incurred by the plants surveyed was minimal, too (Fig. 4), just as in the case of milk collection from farms and production of dairy products. The high quality of products on the one hand and a good collaboration and organization of product deliveries to end customers on the other effectively minimized the volume of goods returned. The most commonly returned products were liquid milk and cream. The share of returns due to complaints (from chain stores, own shops and wholesale warehouses, and other wholesale warehouses) in total product sales of plants surveyed varied in the range of 0.002 to $0.024 \%$ in $2011-2013$. Damage to the packaging was most often mentioned as a cause of complaints and returns to the dairy plants.

These findings suggest that one of the most effective ways to minimize losses of nutrients in the milk product supply chain is to take care of the quality of products and meet the thermal and hygiene conditions (starting from raw milk, through to supervising the whole technological process and the storage of finished products) using relevant production technologies. This allows to 

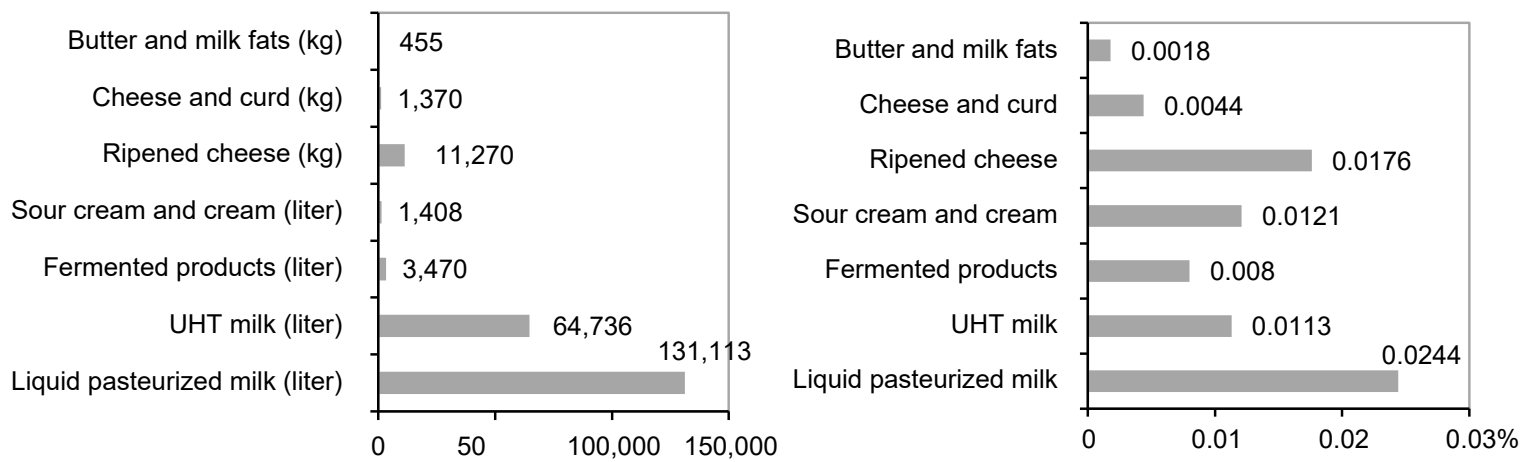

Fig. 4. Total volume of dairy product returns from retail chains, own stores and wholesale facilities, and other wholesalers in 2011-2013 (in liters and $\mathrm{kg}$ and as a percent of sales)

Source: own elaboration based on Seremak-Bulge et al., 2015.

extend the shelf life to $24-42$ days for fresh products (without reducing their quality) and to 180-365 days for durable products.

A significant improvement in the use of nutrients contained in milk produced is also contributed to by a technological progress enabling cost-effective whey processing and by the implementation of what is referred to as product innovations. Whey is the main byproduct generated during milk processing and, until recently, producers have considered it to be troublesome waste used for animal feed or environmentally-unfriendly wastewater requiring treatment. The development of the whey condensation and processing technology enables a cost-effective recovery of valuable whey proteins and other nutrients (mainly lactose). This is why whey has become a valuable raw material enabling a better use of nutrients contained in milk for nutritional purposes. In production of other dairy products, byproducts are either not generated or are processed into fermented products (buttermilk obtained in the production of butter) and fully used for consumption purposes.

The recovery of very valuable whey proteins, lactose, production of cheese and butter with reduced milk fat content, production of reconstituted dairy products etc. helped the plants surveyed in increasing the use of dry matter contained in processed milk from $75.2 \%$ to $98.8 \%$ in 2011 and from $80.4 \%$ to $107.9 \%$ in 2013 . In the dairy plants covered by this study, whey processing contributes not only to increasing their income, but also to reducing the costs of wastewater treatment, which has a positive effect on the profitability of processing. Reducing the risk to the water environment posed by the troublesome wastewater is all the more valuable since whey adds to the pollutant load of the wastewater stream with a very high BOD5 ${ }^{2}$.

The abovementioned activities carried out in dairy plants surveyed are indicative of an effective application of the "Maximizing material and energy efficiency" business model, including a cost reduction through the optimal use of resources at different production stages, which reduces resource losses. These enterprises still face competitive edge and profit opportunities which, however, become exhausted.

Although the Polish dairy industry maintains its cost-price advantages thanks to cheaper raw materials, the problem is the significant fragmentation of dairy plants and the high selling costs. Out of 199 dairy plants operating in 2014, only 21 processed more than 100 million kg of milk per year, of which only two processed more than 1 million tons. In addition, the increasing competition for raw materials raises milk prices and destabilizes the market. Only dairy plants who enjoy a well-grounded position in the Polish market and produce niche products perform better than average. Also, Polish dairy plants are among the smallest in the EU. The two largest plants are located only at the bottom of the world's top thirty largest dairy plants in terms

${ }^{2}$ BOD5: five-day biochemical oxygen demand, an indicator of the amount of wastewater load discharged to the aquatic environment. The higher the indicator, the greater is the demand for oxygen needed to neutralize contamination, and the stronger is the environmental impact. 
of sales value or amount of milk processed (Seremak-Bulge and Mańko, 2014).

The development of the global milk market becomes more and more unpredictable due to increasing trade protectionism, disease threats for dairy cattle or adverse climatic changes. Especially, the latter start to have a growing impact on the situation where global exports of milk and dairy products are dominated by a few exporters (United States, European Union, New Zealand, Australia, Argentina) (European Commission, 2016). Admittedly, it is expected that milk production will increase by $23 \%$ globally by 2024 against the 2012-2014 baseline but the developing (mainly Asian) countries will account for two thirds of that growth. Similarly to milk production, the production volume of dairy products should also increase. It is forecasted that production of fresh products will grow faster than that of processed products, but mostly in the developing countries (ca. 3\%) (OECD-FAO, 2015).

Low profitability, strong competitive pressure and uncertainty of the market environment should therefore encourage Polish dairy plants to seek solutions that will allow them to compete effectively despite the emerging market shocks, and will ensure a sustainable development in the future. Such solutions may be provided by the two next sustainability business models, i.e. Creating value from waste and Substitution with renewables and natural processes.

According to the authors of this paper, future development opportunities should be sought by making stronger efforts to improve the environmental parameters of production processes. Admittedly, the dairy plants surveyed took measures to reduce the consumption of water, the amount of wastewater and the load of pollutants it contains, emissions of gases and dust into the atmosphere and the consumption of heat and electricity. The largest of the plants surveyed upgraded and developed a wastewater treatment facility where biogas is produced in the fermentation process and is then used as fuel to generate energy for technological processes. Also, they commissioned a modern cogeneration plant with a unique exhaust condensation system, contributing to a reduction in carbon emissions into the atmosphere. However, the environmental measures must be continued.

According to a study by Kasztelan and Kierepka (2014), the dairy industry is one of the most water-consuming sectors $(26 \%$ of total water consumption in the
Polish food industry in 2012). To produce butter from $1 \mathrm{dm}^{3}$ of milk, at least $3 \mathrm{dm}^{3}$ of water are consumed; the corresponding volumes for curd and milk powder are ca $4 \mathrm{dm}^{3}$ and $15-20 \mathrm{dm}^{3}$, respectively (Nawirska and Szymański, 2002). This translates into generating a significant amount of wastewater. In 2012, operators active in that sector discharged about $1 / 3$ of the total amount of wastewater in the food industry; nearly half of it was wastewater requiring treatment. However, note that the dairy industry reports the highest percentage of treated wastewater (99.3\%) of all sectors in the Polish food industry.

Milk processing generates significant amounts of packaging waste and various byproducts such as whey, sediments from centrifuges and other equipment, cheese slurry or pieces of cheese. Because of its nutritional value, waste is used as raw materials or intermediate products in producing processed cheese or animal feed. A significant amount of waste generated during milk processing is recycled or landfilled. In addition, the dairy industry (together with the sugar sector) is one of the biggest sources of particulate pollutants (over 32.3\% of the volume generated by the Polish food industry in 2012). Pollutants are released from boiler plants in the form of soot, ash and volatile compounds and dust resulting from production processes. Also, CFCs and ammonia compounds leak out of cooling installations (Kasztelan, 2012).

Sustainability business models are capable of solving the above problems; if implemented, they may provide new sources of competitive advantages in the market. Environmental activities naturally entail large investment inputs. However, benefits can be expected due to reduced environmental fees, improved quality of finished products, enhanced technological processes or reduced consumption of raw materials per production unit. In addition, the implementation of the ISO 14001 Environmental Management System, as it was the case in the largest of the dairy plants surveyed, improves the company's image and competitive position in the market.

While environmental awareness is growing, the social dimension of reducing food losses and waste seems to be more difficult in implementation. A major problem in Poland is the low willingness among producers and processors to participate in providing high-quality milk and dairy products close to expiry date to food banks or other social assistance organizations. The studies 
suggest that while the farmers do not participate in this type of activity, they have a positive view on it. However, they expect the non-profit organizations to handle the logistics and collect agricultural products from the holdings. The dairy plants covered by this analysis were found not to be interested in charity despite the emergence of legal regulations conducive to such activities.

The authors analyzed this phenomenon in Poland and found that surpluses of agricultural products are usually delivered to non-profit organizations if difficult to sell. It was the case, for example, in the apple market following the introduction of the Russian embargo in 2014. Thus, an appropriate information policy is important as it encourages companies to provide those in need with surpluses of food or products close to expiry date. Producers and processors should know where to turn with this problem, or where and under what conditions they may deliver their products. In turn, charities should know the regions of the country which experience problems in commodity management, and how to deliver surpluses to those in need.

There are increasing needs to develop a new business model which would include the distribution of food being wasted. Examples of companies with charitable and commercial functions may already be observed in Western Europe (e.g. Sweden, France). In the Polish context, it is unpopular due to the gap between the economic interest of processors and distributors (in the narrow sense) and the donation of free food to charities. A good example is the approach adopted by "Ben and Jerry" who play an important role in educating the consumers on sustainability issues. This creates brand loyalty and consumer value. They make excellent use of social media and succeed in obtaining a premium price for their products. Such an approach could be adopted not only in the dairy industry but also in other agri-food sub-sectors.

\section{CONCLUSIONS}

The study allows for concluding that losses are marginal at the initial stages of the dairy production chain. Dairy plants have reached a very high level of technological development which allows them to make maximum use of raw materials. Therefore, a significant reduction in processing losses should not be expected. More can be done as regards production of raw milk at farm level; milk losses may be limited by reducing the incidence of mastitis in cows. The largest room for improvements with respect to food losses and food waste prevention exists primarily in the last links of the dairy chain, i.e. trade and consumption.

The literature presents only few studies addressing the volume of losses incurred at different stages of the food chain for various products or sectors. It therefore seems reasonable to carry out similar analyses in other sectors of the agri-food industry, taking the diversity of processing plants (in terms of size and product range) into account. Particular attention should be paid to the fruit and vegetable sector, meat sector and grain/bakery sector which have the largest shares in food losses.

The extent and causes of food losses and food waste cannot be reliably assessed without a sufficient number of representative enterprises whose management agree to participate in the studies and to provide reliable information. So far, traders and processors seem not to be interested in this issue. Without reliable information, it is impossible to properly assess the size and costs of losses in individual value chains. It should be stressed that the total amount of losses at the stages of raw materials delivery, processing and distribution provides a clear picture of losses incurred and benefits derived by the enterprise. If analyses similar to those presented in this paper were carried out in other plants and sectors, it would allow for an improvement of their development strategies. Moreover, most of them declare to have implemented ISO 9001 and ISO 22000 which require internal and external audits and corrective measures.

It may be concluded that thanks to two decades of modernization efforts, the Polish dairy industry has aligned its operations with the sustainability business model focused on maximizing material and energy efficiency. This is evidenced by such activities as the optimal use of resources at different production stages, lower water and energy consumption and reduced emissions of pollutants. However, the existing cost and price advantages of the Polish dairy industry are diminishing, and new stimuli are necessary. Opportunities for further development of dairy companies should be sought by taking a number activities consistent with other sustainability business models which are not only technological, but also social and organizational in nature. In the era of growing competition, their implementation may provide new sources of competitive advantages for enterprises. 
The development of the business models' social dimension seems particularly necessary. In a context of rapid political and economic changes, the social factor will play an increasing role in establishing business conditions for sustainable development. This is not only true for the role of consumers whose product expectations have a growing impact on the selection of a corporate development strategy. A more important problem is the increasing pauperization of a large part of societies affected by low economic availability of food. Therefore, a new business model is needed which would combine commercial and charitable activities to help those in need.

In this regard, greater involvement of the state should be expected; legal regulations should be put in place to encourage enterprises to engage in communitybuilding activities while limiting the potential for fraud. Admittedly, some enterprises (especially retail chains) promote their activities taken to reduce food losses and waste. However, these are quite limited and not very effective.

\section{ACKNOWLEDGEMENTS}

The authors would like to thank Professor Jadwiga Seremak-Bulge for her support in preparing this publication.

\section{SOURCE OF FINANCING}

This paper is the outcome of "The Polish and the EU agricultures $2020+$. Challenges, chances, threats, proposals," the internal 2015-2019 Multi-Annual Program of the Institute of Agricultural and Food Economics National Research Institute based on Warsaw.

\section{REFERENCES}

Afuah, A., Tucci, Ch. L. (2003). Internet Business Models and Strategies: Text and Cases. New York: McGraw-Hill.

Bocken, N. M. P., Short, S., Rana, P., Evans, S. (2013). A value mapping tool for sustainable business modelling. Corp. Gov., 13(5), 482-497. doi: 10.1108/CG-06-2013-0078

Bocken, N. M. P., Short, S. W., Rana, P., Evans, S. (2014). A literature and practice review to develop sustainable business model archetypes. J. Clean. Prod., 65, 42-56. doi: 10.1016/j.jclepro.2013.11.039

Boons, F., Lüdeke-Freund, F. (2013). Business models for sustainable innovation: state-of- the-art and steps towards a research agenda. J. Clean. Prod., 45, 9-19. doi: 10.1016/j. jclepro.2012.07.007

Boons, F., Montalvo, C., Quist, J., Wagner, M. (2013). Sustainable innovation, business models and economic performance: an overview. J. Clean. Prod., 45, 1-8. doi: 10.1016/j.jclepro.2012.08.013

Dairy Technology (2014). Milk Losses in Dairy Plants. Dairy Technology. Retrieved in September 2017 from: http:// dairy-technology.blogspot.com.au/2014/01/milk-lossesin-dairy-plants.html

European Commission (2016). Short-Term Outlook for EU arable crops, dairy and meat markets in 2016 and 2017. European Union.

Jabłoński, A. (2013). Modele zrównoważonego biznesu w budowie długoterminowej wartości przedsiębiorstw z uwzględnieniem ich społecznej odpowiedzialności [Sustainable business models in building long-term value of enterprises with social responsibility]. Warszawa: Difin [in Polish].

Kasztelan, A. (2012). Wpływ przemysłu spożywczego na środowisko naturalne [Food industry impact on the environment in Poland]. Przem. Spoż., 66(11), 12-16 [in Polish].

Kasztelan, A., Kierepka, M. (2014). Oddziaływanie przemysłu spożywczego na środowisko w Polsce [Impact of the food industry on the environment in Poland]. Rocz. Nauk. SERiA, 16(2), 109-116 [in Polish].

Magretta, J. (2002). Why business models matter. Harvard Bus. Rev., 80(5), 86-92.

Nawirska, A., Szymański, L. (2002). Gospodarka wodno-ściekowa w zakładach przemysłu spożywczego [The water-sewage economy in food enterprises]. Wrocław: Wydawnictwo Akademii Rolniczej we Wrocławiu [in Polish].

Obłój, K. (2010). Pasja i dyscyplina strategii. Jak z marzeń i decyzji zbudować sukces firmy [Passion and discipline of strategy. How to build a firm success from dreams and decisions]. Warszawa: Poltext [in Polish].

OECD-FAO (2015). OECD-FAO Agricultural Outlook 2015. Paris: OECD Publishing.

Osterwalder, A., Pigneur, Y. (2010). Business Model Generation: A Handbook for Visionaries, Game Changers, and Challengers. New Jersey: John Wiley \& Sons, Hoboken.

Schaltegger, S., Lüdeke-Freund, F., Hansen, E. G. (2012). Business cases for sustainability: the role of business model innovation for corporate sustainability. Int. J. Innovat. Sustain. Dev., 6(2), 95-119. doi: 10.1504/ IJISD.2012.046944

Seremak-Bulge, J., Grochowska, R., Szczepaniak, I., Szajner, P., Bułkowska, M., Hryszko, K. (2015). Ocena strat ponoszonych na poszczególnych etapach łańcucha mleczarskiego w Polsce [Estimation of losses in dairy chain in 
Poland]. Studia i Monografie, No. 162. Warszawa: Instytut Ekonomiki Rolnictwa i Gospodarki Żywnościowej Państwowy Instytut Badawczy [in Polish].

Seremak-Bulge, J., Mańko, S. (2014). Polskie mleczarstwo 10 lat po integracji z UE [Polish dairy after 10 years of accession to the EU]. Przeg. Mlecz., 10, 15-21 [in Polish].

Teece, D. J. (2010). Business models, business strategy and innovation. Long Range Planning, 43(2-3), 172-194. doi: 10.1016/j.lrp.2009.07.003

Timmers, P. (1998). Business models for electronic markets. Elect. Market., 8(2), 3-8.
Wierzbiński, M. (2015). Model biznesowy a strategia i zarządzanie strategiczne [Business model vs. strategy and strategic management]. Prace Nauk. Uniw. Ekon. we Wrocławiu, 398, 481-499 [in Polish]. doi: 10.15611/ pn.2015.398.46

Zott, Ch., Amit, R. (2010). Business model design: An activity system perspective. Long Range Plann., 43(2-3), 216226. doi: 10.1016/j.lrp.2009.07.004 